\title{
PENGARUH PENGEMBANGAN KARIR DAN MOTIVASI TERHADAP KEPUASAN KERJA KARYAWAN PT POS INDONESIA (PERSERO) BEKASI
}

\author{
Widya Parimita \\ Fakultas Ekonomi Universitas Negeri Jakarta \\ Email: widya_parimita@yahoo.com \\ Laysa Aneu Afrilla Wahda \\ Fakultas Ekonomi Universitas Negeri Jakarta \\ Email: laysaaneu@gmail.com \\ Agung Wahyu Handaru \\ Fakultas Ekonomi Universitas Negeri Jakarta \\ Email: agung_1178@yahoo.com
}

\begin{abstract}
The purpose of this study were: 1) to know the overview of career development, motivation, and job satisfaction the employee at PT Pos Indonesia (Persero) Bekasi. 2) To know the influence of career development on job satisfaction. 3) To know the influence of motivation on job satisfaction. 4) To know the influence of career development and motivation simultaneously on job satisfaction. Research carried out by the simple random sampling method on 154 employees at PT. Pos Indonesia (Persero) Bekasi as respondents, while the technique of data collection is done by distributing questionnaires, which is processed using SPSS 21.0. The research using descriptive and explanatory. The results of the regression indicate that there is influence career development towards job satisfaction and there is influence between motivatiom towards job satisfaction. Career development and motivation simultaneously influence the job satisfaction and significance. This research has figured out the score of career development and motivation on work satisfaction while the rest is influenced by the other factors.
\end{abstract}

Keywords: Career Development, Motivation, Job Satisfaction 


\section{PENDAHULUAN}

Sumber Daya Manusia (SDM) merupakan unsur yang sangat penting dalam suatu perusahaan. Oleh karena itu setiap perusahaan selalu berupaya untuk memiliki SDM yang berkualitas, karena tanpa SDM yang berkualitas suatu perusahaan tidak akan berjalan dengan baik. Antara SDM dan perusahaan harus memiliki hubungan yang saling membutuhkan, perusahaan membutuhkan karyawan yang berkualitas, sementara karyawan membutuhkan perusahaan untuk dapat memenuhi kebutuhan hidupnya.

Setiap perusahaan melakukan berbagai aktivitas untuk mencapai tujuan yang telah ditetapkan sebelumnya, tetapi tidak terlepas dari tujuan utamanya yaitu untuk mensejahterakan dan memajukan kemampuan karyawannya karena karyawan merupakan asset bagi perusahaan. Dan salah satu aktivitas perusahaan untuk memajukan kemampuan karyawannya adalah pengembangan karir karyawan dan memberikan motivasi kepada karyawan. Keberhasilan suatu perusahaan dalam mencapai tujuannya tidak hanya ditentukan oleh struktur organisasi yang lengkap, tetapi juga dipengaruhi oleh faktor penempatan individu pada posisi yang sesuai dan adanya rasa termotivasi bagi mereka dalam melakukan pekerjaan.

Kepuasan kerja merupakan hal yang penting dimiliki oleh setiap orang dalam bekerja. Tingkat kepuasan kerja yang tinggi akan mempengaruhi seseorang dalam menyelesaikan pekerjaannya. Sehingga tujuan perusahaan dapat dicapai dengan baik. Begitupun dengan sebaliknya, rendahnya kepuasan kerja dari karyawan dalam suatu perusahaan akan menurunkan efektifitas dan efisiensi kerja mereka sehingga tujuan perusahaan tidak bisa dicapai dengan baik. Kepuasan kerja pada dasarnya merupakan sesuatu yang sifatnya individual dan setiap individu memiliki tingkat kepuasan yang berbeda-beda. Hal tersebut bisa dilihat dari sikap dan bagaimana cara mereka menyelesaikan suatu pekerjaan yang diberikan. Jika karyawan tersebut menyukai pekerjaannya dan dapat menyelesaikan tugas dari perusahaan dengan baik, maka sudah dapat dipastikan karyawan tersebut memiliki 
rasa puas atas pekerjaannya. Namun pekerjaan itu harus sesuai dengan keahlian dan kemampuan karyawan tersebut, sehingga pekerjaan yang dihasilkan berdampak baik bagi perusahaan. Dan jika pekerjaan itu tidak sesuai dengan keahlian dan kemampuan karyawan, maka bisa menghasilkan dampak buruk seperti menurunnya kinerja dan kepuasan kerja karyawan serta bisa merugikan perusahaan.

Perusahaan harus juga memperhatikan dan mengelola pengembangan karir setiap karyawan dengan baik. Hal ini ditujukan agar karyawan mempunyai kemampuan yang lebih tinggi dari kemampuan yang dimiliki sebelumnya sehingga dapat mengetahui fungsi dan peranan serta tanggung jawabnya di dalam lingkungan kerja. Dengan pengembangan karir juga diharapkan dapat mencapai tingkat kepuasan kerja yang lebih tinggi dan mendapat kejelasan akan jenjang karir yang akan mereka capai. Perusahaan berusaha untuk menumbuhkan kepuasan kerja yang sehat dimana hak dan kewajiban karyawan selaras dengan fungsi peranan dan tanggung jawab karyawannya.

Pemberian motivasi menjadi faktor yang dapat memberikan kepuasan kerja setiap karyawan. Pemberian motivasi sangat penting dilakukan karena biasanya karyawan yang puas dengan apa yang diperolehnya dari perusahaan akan memberikan lebih dari apa yang diharapkan dan mereka akan terus berusaha bekerja dengan baik. Begitupun sebaliknya, karyawan yang kepuasan kerjanya rendah cenderung melihat pekerjaan sebagai hal yang membosankan sehingga mereka bekerja dengan terpaksa dan hasil yang didapat tidak maksimal. Dengan adanya motivasi yang tinggi dalam diri karyawan, diharapkan mereka akan lebih mencintai pekerjaannya, sanggup bekerja dengan baik, dan memiliki loyalitas yang tinggi serta berkeinginan untuk melakukan kinerja yang lebih baik. Kondisi ini diperlukan untuk meningkatkan kepuasan karyawan, jika karyawan mempunyai motivasi tinggi, maka mereka akan terdorong dan berusaha untuk meningkatkan kemampuannya, sehingga akan diperoleh kepuasan yang maksimal.

Dalam perusahaan, pengembangan karir dan pemberian motivasi tentulah bukan pekerjaan yang sederhana. Apalagi jika perusahaan tersebut memiliki 328 Widya Parimita \& Laysa Aneu Afrilla Wahda 
banyak karyawan dalam jumlah besar dan dari berbagai latar belakang budaya, usia, dan pendidikan yang berbeda. Penelitian sebelumnya pernah dilakukan oleh Ekayadi (2010) dengan menggunakan tiga variabel, yaitu motivasi, pengembangan karir dan kepuasan kerja. Dalam penelitiannya ditemukan bahwa dengan motivasi dan pengembangan karir akan meningkatkan kepuasan kerja karyawan. Karena memang kedua hal tersebut sangat dibutuhkan dalam rangka menciptakan hubungan yang harmonis antara perusahaan dengan karyawan yang pada akhirnya diharapkan dapat menciptakan kepuasan kerja yang bagus.

Perusahaan besar tidak menutup kemungkinan memiliki banyak masalah didalamnya. Hasil penelitian yang didapat di PT Pos Indonesia terdapat masalah yang menyangkut sumber daya manusia (SDM) sebagai karyawan dalam perusahaan yang disebabkan karena sebagai seorang individu yang memiliki perbedaan skill, emosi, motivasi, mental dan spiritual. Dalam PT Pos Indonesia, faktor-faktor manusiawi pada diri karyawan tersebut akan berkembang menjadi permasalahan yang kompleks, seperti rendahnya prestasi kerja, rendahnya motivasi kerja, tingginya turnover karyawan, tingginya tingkat ketidakhadiran karyawan yang dapat menghambat perkembangan dan pencapaian tujuan perusahaan.

Berikut ini adalah data absensi ketidak hadiran (alpha) pada karyawan PT Pos Indonesia pada tahun 2011-2013 :

Tabel I. Data Absensi (Alpha) Karyawan PT Pos Indonesia (Persero) Bekasi

Periode Tahun 2011-1013

\begin{tabular}{cc}
\hline TAHUN & JUMLAH KETIDAKHADIRAN \\
& KARYAWAN (HARI) \\
\hline 2011 & 96 \\
\hline 2012 & 110 \\
\hline 2013 & 125 \\
\hline
\end{tabular}

Sumber : PT. Pos Indonesia (Persero) Bekasi 
Dari gambar tabel tersebut terlihat peningkatan jumlah ketidakhadiran karyawan PT Pos Indonesia tiap tahunnya. Tahun 2011 sebanyak 96 ketidakhadiran, tahun 2012 terdapat peningkatan sebanyak 14 orang dengan jumlah total 110 ketidakhadiran, dan tahun 2013 terdapat peningkatan sebanyak 15 orang dengan jumlah total 125 ketidakhadiran.

Data tersebut dapat disimpulkan bahwa rendahnya motivasi mengakibatkan meningkatnya ketidakhadiran karyawan dalam bekerja. Hal ini sesuai dengan penelitian yang dilakukan oleh Mahesa (2010) yang menerangkan bahwa tindakan pelampiasan ketidakpuasan kerja yang dilakukan oleh karyawan adalah keluar dari suatu organisasi atau perusahaan, mengungkapkan secara usaha aktif dan konstruktif untuk memperbaiki kondisi, pasif dalam membela organisasi dan tidak masuk kerja ataupun datang terlambat secara kronis

Dalam hal jenjang karir pun, di PT Pos Indonesia ini tidak jelas. Hasil riset peneliti melalui wawancara, mereka sangat sulit untuk mendapatkan jabatan yang lebih diatasnya. Untuk karyawan biasa, rasanya sulit untuk bisa mendapatkan jabatan tinggi. Karena proses pengembangan karir di PT Pos Indonesia pelaksanaannya belum optimal. Maka dari itu, ketidakjelasan jenjang karir membuat karyawan malas bekerja dan sering tidak hadir di kantor. Sehingga membuat pekerjaan dan tujuan perusahaan tidak bisa dicapai secara maksimal.

Berikut adalah kuesioner wawancara peneliti tentang kepuasan kerja karyawan pada PT Pos Indonesia (Persero) Bekasi

Tabel 2. Kuesioner Kepuasan Kerja Karyawan Pada PT Pos Indonesia (Persero) Bekasi

\begin{tabular}{|c|c|c|c|}
\hline \multirow{3}{*}{ No } & \multirow{3}{*}{ Pernyataan } & \multicolumn{2}{|c|}{ Jawaban } \\
\hline & & \multirow{2}{*}{ Setuju } & Tidak \\
\hline & & & Setuju \\
\hline 1 & $\begin{array}{l}\text { Apakah hubungan interaksi sosial antara } \\
\text { karyawan berjalan dengan baik? }\end{array}$ & 15 & 25 \\
\hline 2 & $\begin{array}{l}\text { Apakah gaji anda telah sesuai dengan } \\
\text { yang diharapkan? }\end{array}$ & 0 & 40 \\
\hline
\end{tabular}




\begin{tabular}{llll}
\hline 3 & $\begin{array}{l}\text { Apakah pekerjaan yang anda dapatkan } \\
\text { sudah sesuai dengan yang diharapkan? }\end{array}$ & 17 & 23 \\
\hline
\end{tabular}

Sumber : Pra Riset data diolah 2014

Tabel diatas menggunakan 40 responden karyawan di kantor pusat PT Pos Indonesia. Penyebaran kuesioner ini dibagikan menggunakan teknik random sample. Hasil pra riset tersebut dapat dilihat bahwa mayoritas responden menjawab tidak pada pernyataan yang diajukan. Hal ini dapat disimpulkan bahwa mayoritas responden mempunyai kepuasan kerja yang rendah. Oleh karena itu fenomena ini tentunya harus menjadi perhatian dan bahan evaluasi perusahaan agar dapat mengelola kepuasan kerja yang lebih baik lagi.

Dari pertanyaan-pertanyaan yang dijawab responden bisa diambil kesimpulan bahwa terdapat ketidakpuasan atas pekerjaan mereka. Dilihat dari hubungan interaksi sosial antara karyawan sepertinya tidak berjalan dengan baik, karena responden banyak yang menjawab tidak. Hubungan interaksi sosial yang baik akan menimbulkan rasa nyaman, ada keharmonisan, rasa dihargai, dan bisa saling memberi dorongan motivasi satu sama lain. Namun pada kenyataannya tidak sesuai harapan. Hal ini yang membuat karyawan kantor pusat PT. Pos Indonesia memiliki produktifitas kerja yang rendah yang pada akhirnya membuat karyawan banyak mangkir dari kantor dan tugas yang dikerjakan tidak maksimal. Seperti yang disampaikan oleh Mathis dan Jackson (2002 : 100) menyatakan, "Seseorang yang tidak puas pada organisasinya akan terlihat menarik diri dari organisasi baik melalui ketidak hadiran atau masuk keluarnya kerja”.

Sedangkan dengan pengembangan karir pada PT Pos Indonesia, persepsi karyawan terhadap pengembangan karir pada perusahaan yang seakan-akan tidak ada perkembangan, karena pengembangan karir seorang karyawan sebagian besar dan lebih diprioritaskan diukur oleh faktor senioritas. Jadi, karyawan-karyawan junior harus bersabar menunggu para senior dan menghabiskan waktunya lebih lama untuk mencapai karir yang lebih baik. Hal ini yang menyebabkan banyak karyawan yang keluar karena bagi mereka itu hanya membuang waktu mereka dengan menunggu jenjang karir yang kurang jelas. Dijelaskan oleh Nurita (2012) 
perencanaan pengembangan karir sangatlah penting bagi karyawan dan merupakan salah satu langkah untuk menimbulkan kepuasan kerja, karena dengan itu karyawan diberi kesempatan untuk tumbuh dan berkembang sesuai dengan potensi yang ada pada mereka. Perusahaan harus benar-benar memperhatikan dan mengelola pengembangan karir dalam perusahaan lebih baik lagi. Pengembangan karir berpengaruh terhadap kepuasan kerja, sehingga perusahaan harus memperhatikan sistem pengembangan karir setiap karyawan perusahaan.

Berdasarkan latar belakang masalah yang telah dijelaskan sebelumnya, peneliti memfokuskan perumusan masalah dalam penelitian ini sebagai berikut:

1. Bagaimana deskripsi pengembangan karir, motivasi, dan kepuasan kerja karyawan PT Pos Indonesia (Persero) Bekasi?

2. Apakah pengembangan karir berpengaruh terhadap kepuasan kerja karyawan PT Pos Indonesia (Persero) Bekasi?

3. Apakah motivasi berpengaruh terhadap kepuasan kerja karyawan PT Pos Indonesia (Persero) Bekasi?

4. Apakah pengembangan karir dan motivasi berpengaruh secara simultan terhadap kepuasan kerja karyawan PT Pos Indonesia (Persero) Bekasi?

5. Seberapa besar kontribusi pengembangan karir dan motivasi terhadap kepuasan kerja karyawan PT Pos Indonesia (Persero) Bekasi?

Tujuan dari penelitian yang dilakukan pada karyawan PT. Pos Indonesia (Persero) Bekasi adalah sebagai berikut:

1. Mengetahui deskripsi dari pengembangan karir, motivasi, dan kepuasan kerja karyawan PT Pos Indonesia (Persero) Bekasi?

2. Menguji secara empiris pengaruh pengembangan karir terhadap kepuasan kerja karyawan PT Pos Indonesia (Persero) Bekasi?

3. Menguji secara empiris motivasi terhadap kepuasan kerja karyawan PT Pos Indonesia (Persero) Bekasi?

4. Menguji secara empiris pengaruh pengembangan karir dan motivasi secara simultan terhadap kepuasan kerja karyawan PT Pos Indonesia (Persero) Bekasi? 
5. Untuk mengetahui seberapa besar kontribusi pengembangan karir dan motivasi terhadap kepuasan kerja karyawan PT Pos Indonesia (Persero) Bekasi

\section{KAJIAN TEORI}

\section{Kepuasan Kerja}

Kepuasan kerja menurut Handoko (2001:193) “Kepuasan kerja adalah pandangan karyawan yang menyenangkan atau tidak menyenangkan terhadap pekerjaan mereka. Perasaan tersebut akan tampak dari sikap positif karyawan terhadap pekerjaan dan segala sesuatu yang dihadapi di lingkungan kerjanya".

Hal tersebut dapat diartikan bahwa kepuasan kerja dapat berdampak pada kecintaan seseorang terhadap pekerjaannya. Pendapat tersebut senanda dengan Hasibuan (2008:202) mengatakan bahwa "Kepuasan kerja adalah sikap emosional yang menyenangkan dan mencintai pekerjaannya. Sikap ini dicerminkan oleh moral kerja, kedisiplinan dan prestasi kerja. Kepuasan kerja dinikmati dalam pekerjaan, luar pekerjaan dan kombinasi dalam dan luar pekerjaan”.

Hal senada juga diungkapkan oleh Rivai dan Sagala (2009:475) yang mengatakan bahwa: "Kepuasan kerja merupakan evaluasi yang menggambarkan seseorang atas perasaan sikapnya, senang atau tidak senang, puas atau tidak puas dalam bekerja". Dari berbagai paparan pendapat tersebut dapat dilihat ada beberapa kesamaan yang mengacu pada menyenangkan atau tidaknya suatu pekerjaan. Sehingga dapat ditarik kesimpulan bahwa kepuasan kerja adalah sikap dan pandangan menyenangkan atau tidak menyenangkan dari karyawan terhadap pekerjaannya. Sikap tersebut mencerminkan perasaaan menyenangkan dan tidak menyenangkan yang ditunjukkan dari berbagai tingkah seseorang. Penelitian ini menggunakan dimensi pekerjaan itu sendiri, hubungan dengan atasan, temen kerja, promosi, dan gaji sebagai pengukurannya.

\section{Pengembangan Karir}

Pengembangan karir menurut Mondy (2010:228) "Pengembangan karir adalah pendekatan formal yang digunakan perusahaan untuk memastikan bahwa 
orang-orang dengan kualifikasi dan pengalaman yang tepat, tersedia saat dibutuhkan".

Pendapat lain dari Mejia (2007:267) yang mengatakan "Pengembangan karir dapat diartikan sebagai upaya formal dan berkelanjutan yang berfokus pada pengembangan terhadap karyawan yang lebih baik".

Hal yang serupa juga diungkapkan oleh H. Hadari Nawawi (2008:289) yang mengatakan bahwa "pengembangan karir adalah usaha yang dilakukan secara formal dan berkelanjutan dengan difokuskan pada peningkatan dan penambahan kemampuan seorang pekerja".

Pendapat tersebut dapat diartikan bahwa pengembangan karir adalah usaha formal untuk meningkatkan dan menambah kemampuan seorang pekerja yang dapat membuka kesempatan untuk mencapai suatu rencana karir selama masa bekerja Penelitian menggunakan dimensi exposure, organizational loyality, dan mentors.

\section{Motivasi}

Menurut Sondang P. Siagian (2002:102) "motivasi merupakan daya dorong bagi seseorang untuk memberikan kontribusi yang sebesar mungkin demi keberhasilan organisasi dalam mencapai tujuan". Dapat diartikan bahwa adanya dorongan pada seseorang akan memberikan kontribusi pada organisasinya sebesar mungkin dalam mencapai tujuan.

Menurut Robbins (2001:166) mengatakan “motivasi yaitu kesediaan untuk mengeluarkan tingkat upaya tinggi untuk tujuan organisasi yang dikondisikan oleh kemampuan upaya itu untuk memenuhi beberapa kebutuhan individual".

Pendapat tersebut selarasa dengan pendapat Malayu S.P Hasibuan (2003:92) menyatakan "Motivasi adalah dorongan yang timbul pada diri seseorang untuk melakukan tindakan karena ingin mencapai tujuan yang dikehendakinya"

Dari pendapat tersebut dapat dilihat persamaan tentang motivasi. Maka dapat disimpulkan motivasi adalah adanya dorongan yang ada pada diri seseorang untuk melakukan suatu perbuatan untuk mencapai tujuan yang dinginkan. Peneliti menggunakan dimensi dorongan dan tujuan. 


\section{Model Penelitian}

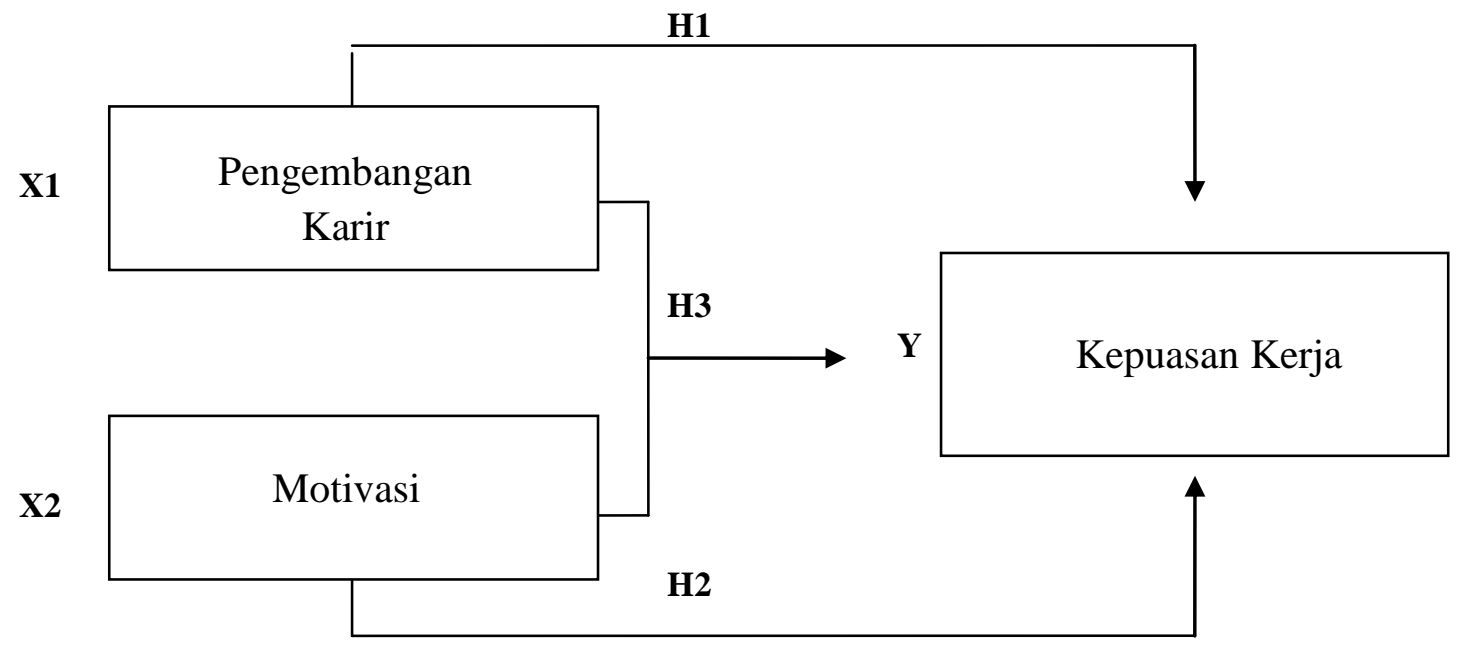

Gambar 1. Model Penelitian

Sumber: Data diolah peneliti, 2015

\section{Hipotesis}

Berdasarkan kajian pustaka dan kerangka pemikiran yang telah dijelaskan sebelumnya, maka penjabaran hipotesis pada penelitian ini adalah sebagai berikut: $\mathrm{H}_{1}$ : Pengembangan karir berpengaruh terhadap Kepuasan kerja karyawan PT Pos Indonesia (Persero) Bekasi.

$\mathrm{H}_{2}$ : Motivasi berpengaruh terhadap Kepuasan kerja karyawan PT Pos Indonesia (Persero) Bekasi.

$\mathrm{H}_{3}$ : Pengembangan karir dan Motivasi secara bersama-sama berpengaruh terhadap Kepuasan kerja karyawan PT Pos Indonesia (Persero) Bekasi.

\section{METODE PENELITIAN}

Penelitian menggunakan metode penelitian deskriptif dan explanatory. Data yang digunakan dalam penelitian ini berasal dari data primer yang didapatkan 
melalui wawancara dan kuesioner, sedangkan data sekunder mengenai data jumlah karyawan diperoleh peneliti melalui PT Pos Indonesia (Persero) Bekasi. Metode pengambilan sampel menggunakan simple random sampling. Jumlah sampel yang digunakan dalam penelitian ini sebanyak 154 responden dari total populasi yang berjumlah 250 sopir dengan menggunakan rumus slovin (dalam Umar, 2008:65) sebagai berikut:

$$
\mathrm{n}=\frac{\mathrm{N}}{1+\mathrm{Ne}^{2}}
$$

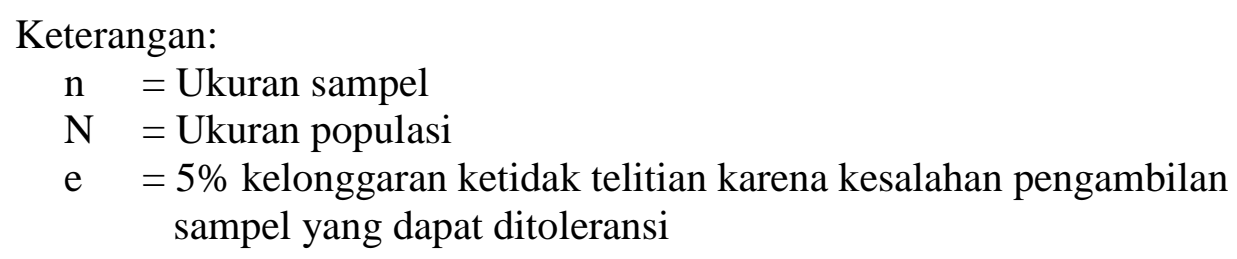

Maka besarnya sampel adalah:

$$
\begin{aligned}
n & =\frac{250}{1+250(0.05)^{2}} \\
& =153,8(154)
\end{aligned}
$$

\section{Uji Instrumen}

\section{Uji Validitas}

Uji validitas digunakan untuk mengukur valid tidaknya suatu kuesioner. Instrumen yang digunakan berupa kuesioner yang diuji coba pada 30 responden karyawan PT Pos Indonesia (Persero) Bekasi. Uji validitas ini dilakukan dengan membandingkan nilai $r_{\text {hitung }}$ dan $r_{\text {tabel }}$ untuk masing-masing butir pernyataan yang ada. Jika nilai $r_{\text {hitung }}>r_{\text {tabel }}$ maka butir instrumen dikatakan Valid. Metode yang digunakan pada pengujian validitas menggunakan pendekatan korelasi product moment dengan ketentuan kevalidan instrument apabila $\mathrm{r}_{\text {hitung }}>\mathrm{r}_{\text {tabel }}$ pada $\mathrm{N}=$ 154. Sehingga didapat nilai $r_{\text {tabel }}$ sebesar 0,361 .

Tabel 3. Hasil Uji Validitas

\begin{tabular}{lccc}
\hline Variabel & $\begin{array}{c}\text { Jumlah item } \\
\text { sebelum diuji }\end{array}$ & $\begin{array}{c}\text { Jumlah item } \\
\text { tidak valid }\end{array}$ & $\begin{array}{c}\text { Jumlah item } \\
\text { valid }\end{array}$ \\
\hline Pengembangan Karir & 11 & 1 & 10 \\
\hline
\end{tabular}




\begin{tabular}{lccc}
\hline Motivasi & 6 & 0 & 6 \\
\hline Kepuasan Kerja & 20 & 0 & 20 \\
\hline
\end{tabular}

Sumber: Data diolah peneliti, 2015

Berdasarkan Tabel 4, hasil uji validitas yang dilakukan pada variabel pengembangan karir, motivasi dan kepuasan kerja menghasilkan nilai $r_{\text {hitung }}$ tiap instrumennya lebih besar dari $r_{\text {tabel }}$, sehingga dapat dapat disimpulkan lihat bahwa seluruh butir pernyataan dalam variabel tersebut valid karena seluruh instrumen telah memenuhi syarat, yaitu nilai $r_{\text {hitung }}>r_{\text {tabel }} 0,361$.

\section{Uji Reliabilitas}

Uji reliabilitas dalam kuesioner penelitian ini menggunakan teknik Cronbach's Alpha, yaitu menunjukkan nilai koefisien reliabilitasnya untuk mengukur besaran nilai positif dari variabel. Jika nilai Cronbach's Alpha> 0,6; maka instrumen penelitian dapat dikatakan reliabel sedangkan Jika nilai Cronbach's Alpha< 0,6; maka instrumen penelitian dikatakan tidak reliabel. Hasil uji reliabilitas untuk masing-masing variabel dapat dilihat pada Tabel 5.

Tabel 4. Hasil Uji Reliabilitas

\begin{tabular}{lcc}
\hline \multicolumn{1}{c}{ Variabel } & Cronbach's Alpha & Keterangan \\
\hline Pengembangan Karir & 0,889 & Reliabel \\
\hline Motivasi & 0,840 & Reliabel \\
\hline Kepuasan Kerja & 0,914 & Reliabel \\
\hline
\end{tabular}

Sumber: Data diolah peneliti, 2015

Pada Table 5 dijelaskan bahwa hasil uji reliabilitas untuk masing-masing variabel dengan menggunakan teknik Cronbach's Alpha, terlihat nilai Cronbach's Alpha $>0,6$; untuk variabel pengembangan karir, motivasi, dan kepuasan kerja secara berurutan sebesar 0,889;0,840; dan 0,914. Jadi, instrumen dari ketiga variabel tersebut dinyatakan reliabel karena nilai Cronbach's Alpha lebih besar dari 0,6 .

\section{Analisis Deskriptif}


Deskripsi data adalah hasil pengolahan data mentah variabel penelitian yang dimaksudkan untuk memberikan gambaran umum mengenai penyebaran dan distribusi data. Data merupakan hasil penelitian ini yang didapat melalui kuisioner yang disebarkan kepada sampel yaitu 154 karyawan PT. Pos Indonesia (Persero) Bekasi

\section{Uji Asumsi Klasik}

\section{Uji Normalitas}

Uji normalitas berguna untuk mengetahui apakah variabel bebas dan variabel terikat dalam penelitian ini keduanya berdistribusi normal, mendekati normal atau tidak. Priyatno (2010:71) menjelaskan uji normalitas digunakan untuk mengukur data skala ordinal,interval maupun rasio. Jika analisis menggunakam metode parametik, maka persyaratan normalitas harus terpenuhi, yaitu data berasal dari distribusi yang normal. Uji normalitas pada penelitian ini menggunakan uji kolmogorov-smirnov dan dikatakan normal jika nilai residual yang terdistribusi secara normal memiliki probabilitas signifikansi $>0,05$.

\section{Uji Linearitas}

Menurut Priyatno (2010:73), uji linearitas bertujuan untuk mengetahui apakah dua variabel mempunyai hubungan yang linear atau tidak secara signifikan. Uji linearitas biasanya digunakan sebagai prasyarat dalam analisis korelasi atau regresi linear. Pengujian dapat dilakukan dengan software Statistical Product and Service Solution (SPSS), dengan menggunakan test for linearity pada taraf signifikasi 0.05. Kriteria dalam uji linearitas adalah dua variabel dikatakan mempunyai hubungan yang linear bila signifikasi (linearity) kurang dari 0.05 (Priyatno, 2010: 73).

\section{Uji Multikolinearitas}

Uji multikolinearitas keadaan dimana terjadi hubungan linier yang sempurna atau mendekati sempurna antar variabel independen dalam model regresi (Priyatno, 2010:81). Uji multikolinearitas berguna untuk mengetahui apakah ada atau tidaknya hubungan linier antar variabel independen dalam model regresi. Mengukur multikoliniearitas dapat diketahui dengan melihat nilai Variance 
Inflation Factor (VIF) pada model regresi. Jika besar VIF $<5$ atau mendekati 1, maka mencerminkan tidak ada multikolinieritas.

\section{Uji Heteroskedastisitas}

Menurut Priyatno (2010:83), uji heteroskedastisitas dilakukan untuk mengetahui apakah dalam sebuah model regresi terjadi ketidaksamaan varian dari residual suatu pengamatan kepengamatan lain.

Metode yang digunakan dalam penelitian ini adalah metode uji Spearman's Rho, yaitu mengkorelasikan nilai residual (unstandardized residual) dengan masing-masing variabel independen. Jika signifikansi kurang dari 0,05, maka terjadi masalah heterokedastisitas.

\section{Uji Hipotesis}

\section{Uji Persamaan Regresi Linear Berganda}

Menurut Priyatno (2010: 61), analisis regresi linear berganda adalah hubungan secara linear antara dua atau lebih variabel bebas dengan variabel terikat. Analisis ini untuk memprediksikan nilai dari variabel terikat apabila nilai variabel bebas mengalami kenaikan atau penurunan dan untuk mengetahui arah hubungan antara variabel bebas dengan variabel terikat, apakah masing-masing variable independen berhubungan positif atau negatif (Priyatno, 2010:61). Model matematis persamaan regresi linear berganda dari penelitian ini adalah:

$\mathbf{Y}^{\prime}=\mathbf{a}+\mathbf{b}_{1} \mathbf{X}_{1}+\mathbf{b}_{2} \mathbf{X}_{2}$

Keterangan:

Y' : Variabel terikat

a : Konstanta

$b_{1}, b_{2}, b_{3}, b_{4}, \quad:$ Koefisien regresi

$\mathrm{X}_{1} \quad$ : Variabel bebas

$\mathrm{X}_{2} \quad$ : Variabel bebas 


\section{Uji F}

Menurut Priyatno (2010:67), uji F digunakan untuk mengetahui apakah variable independen secara bersamaan berpengaruh signifikan terhadap variabel dependen. Pada penelitian ini, uji $\mathrm{F}$ dilakukan untuk menganalisis pengaruh pengembangan karir (X1) dan motivasi (X2) secara bersamaan terhadap kepuasan kerja $(\mathrm{Y})$

$\mathrm{H}_{\mathrm{o}}$ : Pengembangan karir dan motivasi secara bersama-sama tidak berpengaruh terhadap kepuasan kerja.

$\mathrm{H}_{\mathrm{a}}$ : Pengembangan karir dan motivasi secara bersama-sama berpengaruh terhadap kepuasan kerja.

Syarat:

1. $\mathrm{H}_{\mathrm{o}}$ diterima jika $\mathrm{F}_{\text {hitung }}<\mathrm{F}_{\text {table }}$ atau nilai signifikansi lebih besar dari 0.05.

2. $\mathrm{H}_{\mathrm{o}}$ ditolak jika $\mathrm{F}_{\text {hitung }}>\mathrm{F}_{\text {table }}$ atau nilai signifikansi lebih kecil dari 0.05.

\section{Analisis Koefisian Determinasi}

Menurut Priyatno (2010:66), analisis determinasi dalam regresi linear berganda digunakan untuk mengetahui persentase pengaruh sumbangan variabel bebas secara serentak terhadap variabel terikat. Koefisien ini menunjukkan seberapa besar persentase variasi variabel bebas yang digunakan dalam model mampu menjelaskan variasi variabel terikat (Priyatno, 2010:66).

\section{HASIL DAN PEMBAHASAN}

\section{Analisis Deskriptif}

Tabel 5. Nilai Analisis Deskriptif

\begin{tabular}{cccc}
\hline & $\begin{array}{c}\text { Pengembangan } \\
\text { Karir }\end{array}$ & Motivasi & $\begin{array}{c}\text { Kepuasan } \\
\text { Kerja }\end{array}$ \\
\cline { 2 - 4 } Sangat Tidak Setuju & $9,24 \%$ & $14,93 \%$ & $18,73 \%$ \\
\hline Tidak Setuju & $20,05 \%$ & $21,18 \%$ & $24,79 \%$ \\
\hline Netral & $32,51 \%$ & $34,17 \%$ & $26,09 \%$ \\
\hline Setuju & $21,33 \%$ & $16,47 \%$ & $16,94 \%$ \\
\hline Sumbat Setuju & $16,97 \%$ & $13,23 \%$ & $13,86 \%$ \\
\cline { 2 - 4 } & & &
\end{tabular}


Pada Tabel 6 dapat dilihat persentase jawaban yang diberikan oleh para responden yang menggambarkan setiap variabel. Pada variabel pengembangan karir, dapat dilihat bahwa jawaban yang diberikan responden didominasi dengan jawaban Netral yaitu sebesar 32,51\% dan Tidak Setuju dengan persentase 20,05\%. Ini menunjukkan bahwa pengembangan karir yang dialami responden cenderung belum adil. Pada variabel motivasi, hasil persentase terbesar berasal dari jawaban Netral yaitu sebesar 34,17\% dan Tidak Setuju 21,18\% yang menandakan bahwa motivasi yang dialami responden rendah. Selanjutnya, pada variabel kepuasan kerja hasil persentase terbesar berasal dari jawaban Netral yaitu sebesar 26,09\% dan Tidak Setuju yaitu 24,79\%. Hal ini juga menandakan bahwa kepuasan kerja yang dialami responden cenderung rendah.

\section{Hasil Uji Asumsi Klasik}

\section{Uji Normalitas}

Tabel 6. Hasil Uji Normalitas

Tests of Normality

One-Sample Kolmogorov-Smirnov Test

\begin{tabular}{llr}
\hline$N$ & Mean & $\begin{array}{c}\text { Unstandardized } \\
\text { Residual }\end{array}$ \\
\hline Normal Parameters ${ }^{a}$ & Std. Deviation & 154 \\
& Absolute & .0000000 \\
Most Extreme Differences & Positive & 4,94034386 \\
& Negative &, 049 \\
Kolmogorov-Smirnov Z & &, 049 \\
Asymp. Sig. (2-tailed) & &, 035 \\
\hline a. Test distribution is Normal. & &, 860 \\
Sumber : Perhitungan SPSS 21, 2015 & &
\end{tabular}

Berdasarkan uji normalitas pada Tabel 7 dengan menggunakan program SPSS 21 uji kolmogorov-smirnov, dapat dilihat nilai $Z_{\text {hitung }}$ dari penelitian ini adalah 0,603 dengan nilai signifikansi 0,860 lebih besar dari taraf signifikansi yaitu 0,05. Sehingga dapat disimpulkan bahwa semua variabel berdistribusi normal sehingga 
memenuhi syarat dilakukan metode statistik parametrik analisis regresi linear berganda.

\section{Uji Linearitas}

\begin{tabular}{cc}
\multicolumn{2}{c}{ Tabel 7. Hasil Uji Linearitas } \\
\hline Variabel & Nilai Signifikansi \\
\hline Pengembangan Karir * Kepuasan Kerja & 0,000 \\
\hline Motivasi $*$ Kepuasan Kerja & 0,000 \\
\hline Sumber: Perhitungan SPSS 21, 2015
\end{tabular}

Dari Tabel 8, masing-masing variabel $\mathrm{X}$ memiliki nilai signifikansi yaitu variabel pengembangan karir (X1) sebesar 0,000; dan motivasi (X2) sebesar 0,000 sehingga dapat dikatakan bahwa setiap variabel $X$ terdapat hubungan yang linier terhadap Y karena nilai Nilai signifikansi< 0,05 .

\section{Uji Multikolinearitas}

Tabel 8. Hasil Uji Multikolinearitas

\begin{tabular}{|c|c|c|c|c|c|c|c|c|}
\hline \multicolumn{9}{|c|}{ Coefficients $^{a}$} \\
\hline \multirow[b]{3}{*}{ Mod } & & \multirow{2}{*}{\multicolumn{2}{|c|}{$\begin{array}{c}\text { Unstandardized } \\
\text { Coefficients }\end{array}$}} & \multirow{3}{*}{$\begin{array}{c}\text { Standardized } \\
\text { Coefficients } \\
\text { Beta }\end{array}$} & \multirow[b]{3}{*}{$\mathrm{T}$} & \multirow[b]{3}{*}{ Sig. } & \multirow{2}{*}{\multicolumn{2}{|c|}{$\begin{array}{c}\text { Collinearity } \\
\text { Statistics } \\
\end{array}$}} \\
\hline & & & & & & & & \\
\hline & & B & Std. Error & & & & Tolerance & VIF \\
\hline \multirow[t]{5}{*}{1} & (Constant) & 38,355 & 4,491 & & 8,540 & .000 & & \\
\hline & Pengemb & ,332 & ,105 & ,218 & 3,171 & & & \\
\hline & angan & & & & & .002 & .815 & 1.227 \\
\hline & karir & & & & & & & \\
\hline & motivasi & 1,235 & ,163 & ,520 & 7,556 & .000 & .815 & 1.227 \\
\hline
\end{tabular}

a. Dependent Variable: kep_ker

Sumber: Perhitungan SPSS 21, 2015

Berdasarkan hasil uji multikolinearitas pada Tabel 9 dengan menggunakan statistik pengolahan data, diketahui angka VIF untuk variabel pengembangan karir dan motivasi secara berurutan yaitu sebesar 1,227; dan 1,227. Nilai VIF dari 
seluruh variabel bebas adalah kurang dari 5, maka di antara kedua variabel bebas tersebut tidak ditemukan adanya masalah multikolinearitas.

\section{Uji Heteroskedastisitas}

Tabel 9. Hasil Uji Heterokedastisita

Correlations

\begin{tabular}{|c|c|c|c|c|c|}
\hline & & & $\begin{array}{c}\text { Pengemba } \\
\text { ngan karir }\end{array}$ & motivasi & $\begin{array}{c}\text { Unstandardized } \\
\text { Residual }\end{array}$ \\
\hline \multirow[t]{12}{*}{ Spearman's rho } & Pengembangan & Correlation & 1,000 &, $290^{* *}$ &,- 059 \\
\hline & Karir & Coefficient & & & \\
\hline & & Sig. (2-tailed) & . & ,000 & ,464 \\
\hline & & $\mathrm{N}$ & 154 & 154 & 154 \\
\hline & Motivasi & Correlation &, $290^{* *}$ & 1,000 & ,020 \\
\hline & & Coefficient & & & \\
\hline & & Sig. (2-tailed) &, 000 & . & ,807 \\
\hline & & $\mathrm{N}$ & 154 & 154 & 154 \\
\hline & Unstandardized & Correlation &,- 059 & ,020 & 1,000 \\
\hline & Residual & Coefficient & & & \\
\hline & & Sig. (2-tailed) & ,464 & ,807 & . \\
\hline & & $\mathrm{N}$ & 154 & 154 & 154 \\
\hline
\end{tabular}

${ }^{* *}$. Correlation is significant at the 0.01 level (2-tailed).

Sumber: Perhitungan SPSS 21, 2015

Pada Tabel 10, diketahui korelasi antara pengembangan karir dengan unstandardized residual menghasilkan nilai signifikasi 0,464; korelasi antara motivasi dengan unstandardized residual menghasilkan nilai 0,807. Jadi, dapat disimpulkan bahwa pada model regresi tidak ditemukan adanya masalah heteroskedastisitas, hal ini karena nilai signifikasi korelasi lebih besar dari 0,05. 


\section{Uji Hipotesis}

\section{Hasil Persamaan Regresi Linear Sederhana}

Tabel 10. Hasil Persamaan Regresi Linier Sederhana

\begin{tabular}{|c|c|c|c|c|c|}
\hline \multicolumn{6}{|c|}{ Coefficients $^{\mathrm{a}}$} \\
\hline \multirow[t]{3}{*}{ Model } & \multirow{2}{*}{\multicolumn{2}{|c|}{$\begin{array}{c}\text { Unstandardized } \\
\text { Coefficients }\end{array}$}} & \multirow{3}{*}{$\begin{array}{c}\text { Standardized } \\
\text { Coefficients } \\
\text { Beta }\end{array}$} & \multirow[t]{3}{*}{$\mathrm{T}$} & \multirow[t]{3}{*}{ Sig. } \\
\hline & & & & & \\
\hline & $\mathrm{B}$ & Std. Error & & & \\
\hline (Constant) & 52,788 & 4,756 & & 11,100 & ,000 \\
\hline pengembangan & ,672 & , 110 & ,442 & 6,081 &, 000 \\
\hline karir & & & & & \\
\hline
\end{tabular}

a. Dependent Variable: Kepuasan Kerja

Sumber: Perhitungan SPSS 21, 2015

Tabel 11 menunujukkan nilai signifikansi pada variabel pengembangan karir sebesar 0,000 dan lebih kecil dari 0,05. Sehingga kesimpulan yang diambil adalah $\mathrm{H}_{\mathrm{o}}$ ditolak dan $\mathrm{H}_{\mathrm{a}}$ diterima. Dengan demikian pengembangan karir berpengaruh positif terhadap kepuasan kerja.

Tabel 11. Hasil Persamaan Regresi Linier Sederhana

\begin{tabular}{|c|c|c|c|c|c|c|}
\hline \multicolumn{7}{|c|}{ Coefficients $^{\mathrm{a}}$} \\
\hline \multirow[t]{2}{*}{ Model } & & \multicolumn{2}{|c|}{$\begin{array}{c}\text { Unstandardized } \\
\text { Coefficients }\end{array}$} & \multirow{2}{*}{$\begin{array}{c}\text { Standardized } \\
\text { Coefficients }\end{array}$} & \multirow[t]{2}{*}{$\mathrm{T}$} & \multirow[t]{2}{*}{ Sig. } \\
\hline & & $\mathrm{B}$ & Std. Error & & & \\
\hline \multirow[t]{2}{*}{1} & (Constant) & 47,328 & 3,590 & & 13,183 & ,000 \\
\hline & Motivasi & 1,458 & , 152 & ,614 & 9,600 &, 000 \\
\hline
\end{tabular}


a. Dependent Variable: Kepuasan Kerja

Tabel 11 menunujukkan nilai signifikansi pada variabel motivasi sebesar 0,000 dan lebih kecil dari 0,05. Sehingga kesimpulan yang diambil adalah $H_{o}$ ditolak dan $\mathrm{H}_{\mathrm{a}}$ diterima. Dengan demikian motivasi berpengaruh positif terhadap kepuasan kerja.

\section{Hasil Persamaan Regresi Linear Berganda}

Tabel 12. Hasil Persamaan Regresi Linier Berganda

\begin{tabular}{|c|c|c|c|c|c|c|}
\hline & & \multicolumn{5}{|c|}{ Coefficients $^{a}$} \\
\hline \multirow{3}{*}{\multicolumn{2}{|c|}{ Model }} & \multirow{2}{*}{\multicolumn{2}{|c|}{$\begin{array}{l}\text { Unstandardized } \\
\text { Coefficients }\end{array}$}} & \multirow{3}{*}{$\begin{array}{c}\text { Standardized } \\
\text { Coefficients } \\
\text { Beta }\end{array}$} & \multirow[b]{3}{*}{$\mathrm{T}$} & \multirow[b]{3}{*}{ Sig. } \\
\hline & & & & & & \\
\hline & & B & Std. Error & & & \\
\hline \multirow[t]{3}{*}{1} & (Constant) & 38,355 & 4,491 & & 8,540 & .000 \\
\hline & $\begin{array}{l}\text { Pengemban } \\
\text { gan karir }\end{array}$ & ,332 & 105 & ,218 & 3,171 & .002 \\
\hline & motivasi & 1,235 & , 163 & ,520 & 7,556 & .000 \\
\hline
\end{tabular}

a. Dependent Variable: kep_ker

Sumber: Perhitungan SPSS 21, 2015

Tabel 11 menunujukkan nilai signifikansi pada variabel pengembangan karir sebesar 0,002 dan lebih kecil dari 0,05. Sehingga kesimpulan yang diambil adalah $\mathrm{H}_{\mathrm{o}}$ ditolak dan $\mathrm{H}_{\mathrm{a}}$ diterima. Dengan demikian pengembangan karir berpengaruh positif terhadap kepuasan kerja.

Tabel 11 juga menunjukkan nilai signifikansi pada variabel motivasi sebesar 0,000 dan lebih kecil dari 0.05. Sehingga kesimpulan yang diambil adalah $\mathrm{H}_{\mathrm{o}}$ ditolak dan $\mathrm{H}_{\mathrm{a}}$ diterima. Yang berarti motivasi berpengaruh positif terhadap kepuasan kerja.

Berdasarkan Tabel 11, model persamaan regresi linear yang didapat adalah $Y=38,355+0,332 X 1+1,235 X 2$. Arti dari angka-angka tersebut adalah: Nilai koefisien regresi variabel pengembangan karir bernilai positif, yaitu 0,332. Dapat diartikan bahwa setiap peningkatan satu skor pengembangan karir maka akan menurunkan kepuasan kerja sebesar 0,332 skor dengan variabel motivasi tetap. 
Nilai koefisien regresi variabel motivasi juga bernilai positif, yaitu 1,235. Dapat diartikan bahwa setiap peningkatan satu skor motivasi maka akan menurunkan kepuasan kerja sebesar 1,235 skor dengan variabel pengembangan karir tetap.

\section{Hasil Uji F}

Tabel 13. Hasil Uji F

\begin{tabular}{|c|c|c|c|c|c|c|}
\hline \multicolumn{7}{|c|}{ ANOVA $^{b}$} \\
\hline Model & & Sum of Squares & $\mathrm{Df}$ & Mean Square & $\mathrm{F}$ & Sig. \\
\hline \multirow[t]{3}{*}{1} & Regression & 2663,580 & 2 & 1331,790 & 53,853 &, $000^{\mathrm{b}}$ \\
\hline & Residual & 3734,271 & 151 & 24,730 & & \\
\hline & Total & 6397,851 & 153 & & & \\
\hline
\end{tabular}

a. Predictors: (Constant), motivasi, pengembangan karir

b. Dependent Variable: kepuasan kerja

Sumber : Perhitungan SPSS 21, 2015

Pada Tabel 12 menunjukkan bahwa signifikansi pada uji $\mathrm{F}$ sebesar 0,000; dengan demikian lebih kecil dari 0,05. Kesimpulan yang dapat diambil variabel pengembangan karir dan motivasi berpengaruh terhadap variabel dependen kepuasan kerja.

\section{Hasil Analisis Determinasi}

Analisis determinasi diperlukan untuk mengetahui seberapa besar persentase pengaruh variabel independen terhadap variabel dependen. Berikut adalah hasil analisis determinasi antara variabel pengembangan karir, motivasi, dan kepuasan kerja.

Tabel 14. Hasil Analisis Determinasi

Model Summary

\begin{tabular}{llrrr} 
Model & R & R Square & Adjusted R Square & Std. Error of the Estimate \\
\hline 1 &, $645^{\mathrm{a}}$ &, 416 &, 409 & 4,973 \\
\hline
\end{tabular}




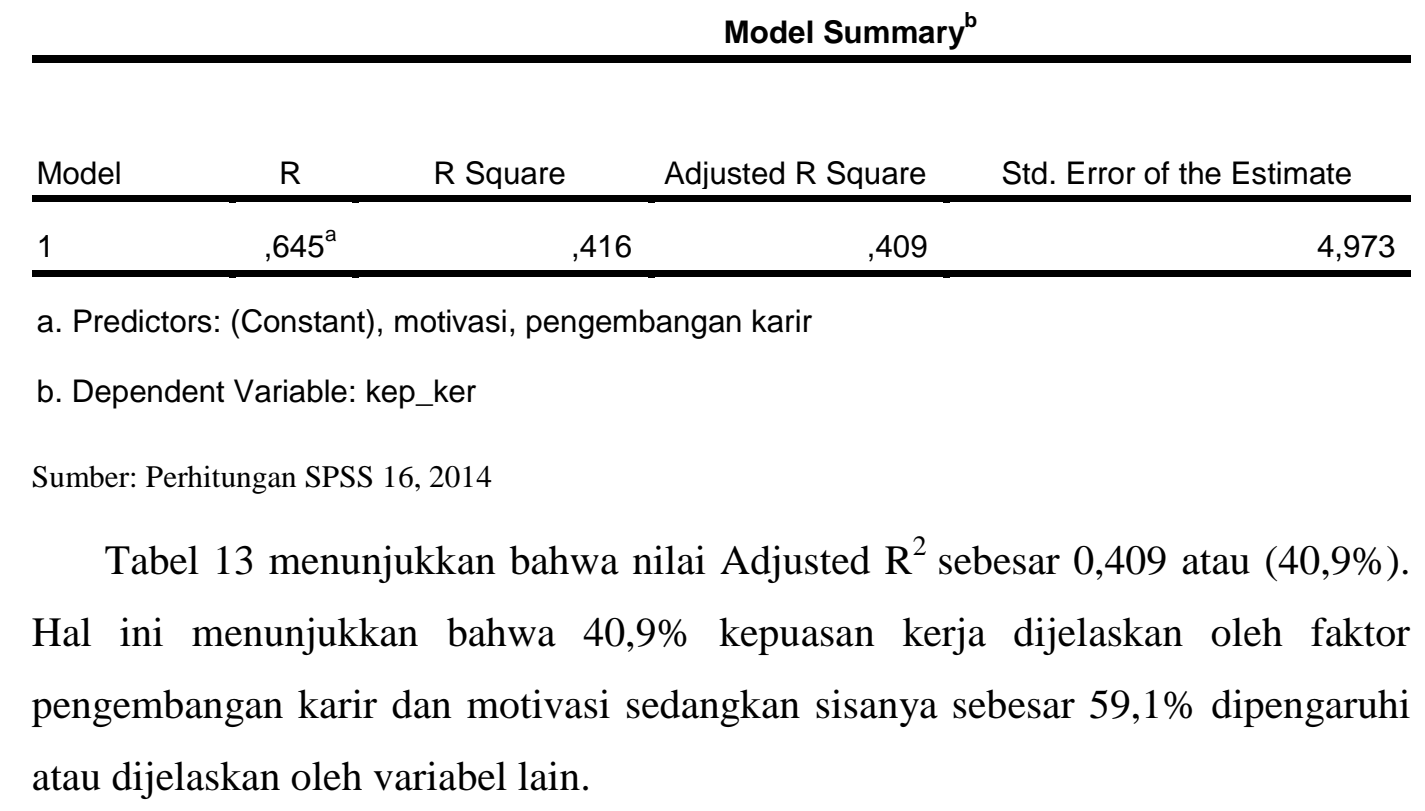

\section{KESIMPULAN DAN SARAN}

\section{Kesimpulan}

Berdasarkan hasil penelitian mengenai Pengaruh Pengembangan Karir dan Motivasi terhadap Kepuasan Kerja Karyawan PT Pos Indonesia (Persero) Bekasi, maka dapat diambil kesimpulan sebagai berikut:

1. Pengembangan karir memiliki pengaruh yang positif dan signifikan terhadap Kepuasan kerja karyawan PT Pos Indonesia (Persero) Bekasi.

2. Motivasi memiliki pengaruh yang positif dan signifikan terhadap Kepuasan kerja karyawan PT Pos Indonesia (Persero) Bekasi.

3. Pengembangan karir dan motivasi sama-sama memiliki pengaruh yang positif terhadap Kepuasan kerja karyawan PT Pos Indonesia (Persero) Bekasi.

\section{Saran-Saran}

Berdasarkan kesimpulan di atas, beberapa saran yang dapat diajukan dalam penelitian adalah sebagai berikut:

Pihak PT Pos Indonesia (Persero) Bekasi diharapkan lebih memperhatikan masalah yang dihadapi para karyawan dengan cara membuka kesempatan pada 
karyawan untuk mengembangkan karir mereka, menjalin hubungan yang baik antara atasan dengan bawahan dan membimbing karyawan dalam setiap kegiatan perusahaan.

Pihak PT Pos Indonesia (Persero) Bekasi diharapkan lebih memperhatikan hal ini memberikan pekerjaan-pekerjaan yang menantang bagi karyawan, memberi kesempatan karyawan untuk mencoba hal-hal baru, dan selalu memberi bantuan kepada karyawan jika mengalami kesulitan dalam bekerja. Serta memperhatikan hal-hal yang mempengaruhi kepuasan kerja karyawan. Hal ini dapat dilakukan dengan cara meningkatkan gaji pada karyawan sesuai dengan masa kerja mereka.

\section{DAFTAR RUJUKAN}

Bernardin, H. John. 2003. Human Resource Management: An Experiental Approach. $3^{\text {rd }}$ ed. New York: McGraw-Hill.

Dessler, Gary. 2013. Human Resource Management $13^{\text {th }}$ edition, New York: Pearson Education.

Ekayadi, S. (2009). Pengaruh Motivasi dan Pengembangan Karir Terhadap Kepuasan Kerja Karyawan pada PT. Rimbajatiraya Citrakarya. (TA No. 11205542/2006). Unpublished postgraduated thesis, Universitas Gunadarma.

Gomez, Luis R-Meija, et al. 2007. Managing Human Resources, Fifth Edition, New York: Pearson Education.

Handoko, Hani T. 2008. Manajemen Personalia dan Sumber Daya Manusia. Yogyakarta: BPFE-Yogyakarta.

Hasibuan. 2008. Manajemen Sumberdaya Manusia. Bumi Aksara. Jakarta. Hal.202.

Hasibuan, M. S. P. 2005. Manajemen Sumber Daya Manusia. Edisi Revisi. Jakarta: Bumi Aksara.

http://www.posindonesia.co.id/index.php/profil-perusahaan/sejarah-pos diakses pada tanggal 8 Desember 2014. 
http://jurnal-sdm.blogspot.com/2009/04/teori-teori-tentang-kepuasan-kerjadan.html diakses pada tanggal 8 Desember 2014

https://teorionline.wordpress.com/category/kumpulan-teori/teori-motivasi/ diakses pada tanggal 9 Desember 2014

http://ekonomi.kompasiana.com/manajemen/2011/07/06/definisikarier378941.htl diakses pada tanggal 25 Desember 2014

http://id.wikipedia.org/wiki/Karier diakses pada tanggal 2 Januari 2015

Kreitner, R, dan A. Kinicki. 2001. Organizational Behavior. Fifth Edition. Mc. Graw Hill Education. New York. pp. 224.

Kadarisman M. 2012. Manajemen Pengembangan Sumber Daya Manusia, Jakarta: PT. Rajagrafindo Persada.

Lussier, Robert N. 2010. Human Relations In Organization: Applications and Skill Building, Eight Edition, New York: McGraw-Hill/Irwin.

Mahesa, Deewar. 2010. Analisis Pengaruh Motivasi dan Kepuasan Kerja Terhadap Kinerja Karyawan dengan Lama Kerja Sebagai Variabel Moderating. Skripsi: Universitas Diponegoro

Mangkuprawira, Sjafri. 2011. Manajemen Sumber Daya Manusia Edisi Kedua, Bogor: Ghalia Indonesia.

Mangkunegara, A.A Anwar Prabu. 2009. Manajemen Sumber Daya Manusia Perusahaan. Bandung: PT. Remaja Rosdakarya

Mathis, Robert L, and John H. Jackson. 2001. Manajemen Sumber Daya Manusia (Human Resources Management, $9^{\text {th }}$ Edition), Jakarta: Salemba Empat.

Moekijat. 1995. Manajemen Personalia dan Sumber Daya Manusia, Bandung: Mandar Maju.

Mondy, Wayne R and Judy Bandy Mondy. 2012. Human Resource Management Twelfth Edition, England: Pearson Education Limited. 
Natalia, Ajiningtyasasih. 2011. Hubungan Antara Budaya Organisasi Dan

Motivasi Dengan Pengembangan Karir Pegawai Di Biro Kepegawaian Dan Organisasi Tatalaksana Kementrian Pekerjaan Umum Jakarta Selatan. Jurnal penelitian: Universitas Negeri Jakarta.

Nawawi, Hadari. 2008. Manajemen Sumber Daya Manusia untuk Bisnis yang Kompetitif, Yogyakarta: Gajah Mada University Press.

Panggabean, Mutiara S., 2004. Manajemen Sumber Daya Manusia. Bogor: Ghalia Indonesia.

Priyatno, Duwi. 2009. Mandiri Belajar SPSS. Yogyakarta: Mediakom.

Priyatno, Duwi. 2009. 5 Jam Belajar Olah Data dengan SPSS 17. Yogyakarta: Penerbit Andi

Rivai, Veithzal dan Ela Jauvani Segala. 2010. Manajemen Sumber Daya Manusia untuk Perusahaan : Dari Teori ke Praktik. Jakarta : Raja Grafindo Persada.

Robbins, Stephen P. dan Timothy, A. Judge. 2008. Perilaku Organisasi. Salemba Empat. Jakarta.

Robbins, Stephen P dan Timothy A. Judge. 2009. Perilaku organisasi. Jakarta: Salemba Empat.

Robbins, Stephen P dan Timothy A. Judge. 2011. Organizational Behavior. New Jersey: Pearson Education, Inc.

Sari, S Nurita. Pengaruh Pengembangan Karir Terhadap Kepuasan Kerja Pegawai di Kantor Kecamatan Gurah Kabupaten Kediri, Jurnal Ilmu Manajemen: Revitalisasi, Vol. 1, Nomor 2, September 2012, ISNN: 2301-5187.

Sondang, P Siagian. 2007. Teori Dan Praktek Kepemimpinan. PT. Rineka Cipta. Jakarta.

Sunyoto, Danang. 2012. Manajemen Sumber Daya Manusia. Yogyakarta: PT. Buku Seru

Tim Penyusun. 2008. Pedoman Penulisan Skripsi Sarjana Ekonomi. Jakarta : FE

350 Widya Parimita \& Laysa Aneu Afrilla Wahda 
Jurnal Riset Manajemen Sains Indonesia (JRMSI) | Vol 6, No. 1, 2015

UNJ.

Zahra, Nur Azizah. 2013. Hubungan Antara Pengembangan Karir Dengan

Kepuasan Kerja Pada Karyawan PT. Fondanusa Aditama Cikarang. Skripsi : Universitas Negeri Jakarta. 